\title{
Sustainable and low-cost automated greenhouse prototype with a social focus for integral formation
}

\section{Prototipo de invernadero automatizado sustentable y de bajo costo con enfoque social para la formación integral}

ÁLVAREZ-TORRES, Norma Angélica†*, VELARDE-ANAYA, Omar, RODRÍGUEZ-ARENAS, Mario Balvanedo and TORRES-ÁLVAREZ, Sara

Universidad Tecnológica de Nogales, Sonora. Avenida Universidad \#271, CP. 84000, Nogales, Sonora.

ID $1^{\text {st }}$ Author: Norma Angélica, Álvarez-Torres / ORC ID: 0000-0002-7075-0945, Researcher ID Thomson: F-2959-2018, CVU CONACYT ID: 897854

ID $1^{\text {st }}$ Co-author: Omar, Velarde-Anaya / ORC ID: 0000-0001-8365-5755, Researcher ID Thomson: G-5062-2018, CVU CONACYT ID: 454555

ID $2^{\text {nd }}$ Co-author: Mario Balvanedo, Rodríguez-Arenas / ORC ID: 0000-0001-6779-1546, Researcher ID Thomson: I6610-2018, CVU CONACYT ID: 874822

ID $3^{\text {rd }}$ Co-author: Sara, Torres-Álvarez / ORC ID: 0000-0001-6211-4386, Researcher ID Thomson: F-8192-2018, CVU CONACYT ID: 899334

DOI: $10.35429 /$ JTI.2021.23.8.6.13

Received July 15, 2021; Accepted December 30, 2021

\begin{abstract}
A low-cost automated greenhouse prototype was developed, which can be installed on rooftops, gardens, and even commercial greenhouses. This work was carried out through the use of an electronic control system, and a user interface, which allows it to be used by children, young people or adults of the Private Assistance Institution (IAP) "Manitas que hablan", contributing to the cultivation of flowers, herbs, fruits and vegetables. Surveys, experimental and observation was applied wish methodology of during the development of this project, to know the needs of the agricultural sector and to integrate the components of the systems for the automated greenhouse. The study demonstrates the feasibility of collaborative work in the development of a prototype that allows the germination of seeds and harvest of crops, and the importance of providing support to the social sector, promoting urban gardens for the integration of children and young people in this activity, achieving better health and food safety for the future.
\end{abstract}

Automated greenhose, Low cost, Integral formation

\section{Resumen}

Se desarrolló un prototipo de invernadero automatizado de bajo costo, que puede instalarse en azoteas, jardines e incluso invernaderos comerciales. Este trabajo se realizó por medio del uso de un sistema de control electrónico, y una interfaz de usuario, que permite ser utilizada por niños, jóvenes o adultos de la Institución del Asistencia Privada (IAP) "Manitas que Hablan", para contribuir al cultivo de flores, hierbas, frutas y verduras. Durante el desarrollo del presente proyecto, se aplicó la metodología de encuestas, experimental y observación, para conocer las necesidades del sector agrícola e integrar de manera adecuada los componentes de los sistemas que forman parte del invernadero automatizado. El estudio demuestra la factibilidad del trabajo colaborativo en el desarrollo de un prototipo que permite la germinación de semillas y cosecha de cultivos, así como la importancia de brindar apoyo al sector social promoviendo huertos urbanos para la integración de niños y jóvenes en esta actividad, logrando una mayor salud y seguridad alimentaria para el futuro.

Invernadero automatizado, Bajo costo, Formación integral

Citation: ÁLVAREZ-TORRES, Norma Angélica, VELARDE-ANAYA, Omar, RODRÍGUEZ-ARENAS, Mario Balvanedo and TORRES-ÁLVAREZ, Sara. Sustainable and low-cost automated greenhouse prototype with a social focus for integral formation. Journal of Technology and Innovation. 2021. 8-23:6-13.

\footnotetext{
* Correspondence of the Author (Email: naat80@ hotmail.com)

$\dagger$ Researcher contributing as first author.
} 


\section{Introduction}

The greenhouse effect is a natural and beneficial phenomenon for human beings since some gases in the atmosphere maintain the thermal radiation emitted by the earth when heated by the sun, allowing an adequate temperature to live on the planet. However, the life expectancy of the human being increases year by year, in this way the countries present an upward trend towards population growth, and its deforestation for the construction of housing, water shortages, as well as climate change.

These human actions have increased the presence of carbon dioxide and methane, which causes global warming, that is, an increase in heat retention and temperature. One of the consequences of the greenhouse effect is present in agriculture and livestock, the variation in temperature influences crops and livestock reproduction.

The Food and Agriculture Organization of the United Nations (FAO), (Agricultura, s.f.), warns about the need to achieve efficient, equitable and sustainable use of water in agriculture, since a decrease in agricultural production, it would result in a food shortage. In addition to this, the United Nations (Unidas, s.f.) predicts that the world population will increase by 2000 million people in the next 30 years; from 7,700 to 9,700 million people in 2050 .

Food security is of utmost importance and of international alert to the increase in the world population and risks of not being able to produce enough food due to the effects of climate change on the soil and the reduction of water available for agriculture. (Pérez Vázquez Arturo, 2018).

Mexico has 1 million 964 thousand 375 $\mathrm{km} 375 \mathrm{~km}^{2}$ of territorial surface, which places it in the 13th largest nation in the world (SIAP, 2019). The population in 2020 was 126 million people (INEGI, 2020), converting it the 10th most populated nation in the world (Population, 2020). The high growth of the country implies a difficulty in meeting food needs, as well as importing food.
Nogales, Sonora, has very little or no agricultural activity, mainly due to its orography, lack of regular rainfall during the year, and extreme weather $\left(-10^{\circ} \mathrm{C}\right.$ winter and $40^{\circ} \mathrm{C}$ summer). Therefore, the most important economic activity in the municipality is the foreign export manufacturing and assembly industry. Added to this, according to the results of the Centro de Población y Vivienta 2020, it is currently the seventh most populated border city in Mexico. As expected, all these variables limit food security in the region, in terms of access to fresh natural products, such as fruits and vegetables. (INEGI, 2020)

Therefore, this work aims to promote the generation of urban gardens, relying on the use of a greenhouse developed with low-cost technology, since it contributes to a significant improvement in the variety of crops in extreme climates regions, it can satisfy food production of a person monthly consumption in a $1 \mathrm{~m}^{2}$ land surface area and promotes the saving of water for irrigation, as well as comprehensive training, through a culture of cultivation from the new generations that are part of the institutions social, to the community in general.

They present the materials, stages, development methodology used for the development of the systems that are part of the prototype, tests, and results obtained are presented.

\section{Materials and methods}

Nogales, Sonora, is located in the north of Sonora, México, the territory is generally mountainous, it has a temperate semi-dry climate BS1Kw (x) (e) (García, 2004). In 2021, it has registered a maximum temperature of $43^{\circ}$ $\mathrm{C}$ in June and $-6^{\circ} \mathrm{C}$ in January (Wheather, 2021). The municipality climatic analysis showed that in the winter season low temperatures and few sunny days are registered; strong wind speeds; abundant rainfall and constant freezing, that do not allow the growth of plants outside. Therefore, a structure capable of withstanding all these conditions is recommended. 
To determine the materials used in the greenhouse prototype, a previous analysis was carried out on the space and factors in which it will be installed. A type of tunnel or semicircle greenhouse was determined, which is characterized by its roof shape and metal structure. This type of greenhouses guarantees a greater control in the capacity of the climatic factors, in addition, it has great resistance to strong winds and its speed of installation as they are prefabricated structures, likewise, being totally curved, it prevents puddles on the roofs and humidity. It can be seen in Figure 1, the 3D design, in which two levels are appreciated. The lower one will be used as a water container, in such a way that the liquid supply to the greenhouse plants is achieved when necessary. The superior to carry out a stage of germination and cultivation of the seed.

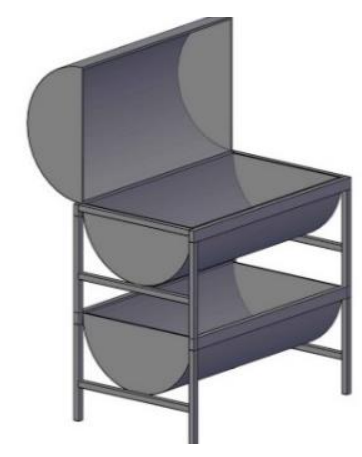

Figure 13D design of the prototype Source: Own elaboration

The base of the trunk contains a drain, so that, when the plants are watered, (approximately $50 \%$ of the watered water is transferred, $25 \%$ corresponds to the roots and the other $25 \%$ will be the surplus; the other $50 \%$ of the water $(15 \%$ remains on the surface and the remaining $35 \%$ is gasified), all the surplus passes through the conduit and reaches the tank with water located in the lower part of the structure, thus achieving the reuse of the liquid, and turning it into a self-sustaining water supply system. The lid, which corresponds to the movable part of the trunk, when closed, forms a curved structure, complying with the design characteristic. The inner part of the cover is intended to support the assembly of the circuits and tools necessary for the automated greenhouse.
The free Arduino hardware platform is used, whose compatibility, low price, and friendly programming make it a viable alternative for your application. Arduino is a digital processing tool similar to a computer, it allows to control and acquire data in a simple way and these actions are necessary to carry out the control of the various systems that are part of the greenhouse. Of the different models that exist, the Arduino UNO board (Figure 2) was used to obtain data from the various systems.

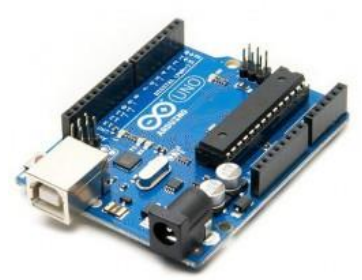

Figure 2 Arduino UNO

Source: https://elecan3d.com/arduino/52-arduinouno-r3.html

To measure the temperature, the digital sensor Ds18b20 (Figure 3) was used, which is covered and sealed, optimal characteristics for this system.

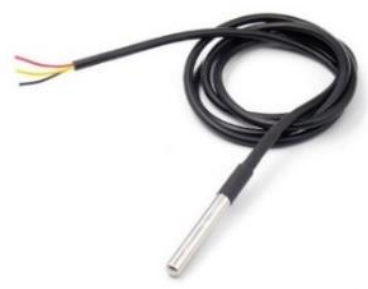

Figure 3 Sensor Ds 18 b20

Source:

http://chips.mecatronium.com/product/sensor-detemperatura-ds18b20-digital-tipo-sondasumergible-1m/

As thermal elements to control the temperature inside the greenhouse, two Peltier cells were included (Figure 4). These elements work under the effect of the same name, which is characterized by the appearance of a temperature difference between the two faces of a semiconductor when current flows through it. (Sandoval G. Arturo P., 2008) 


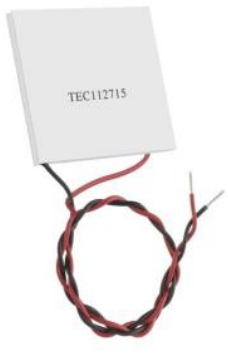

Figure 4 Peltier Cell

Source: https://www.steren.com.mx/celda-peltier40-x-40mm.html

Another method for applied ventilation and cooling was the adaptation of PC fans (Figure 5), which were chosen due to their size and voltage consumption. Two fans were placed on the side of the lid and a third fan placed on the heat sink of the cells, for better performance.

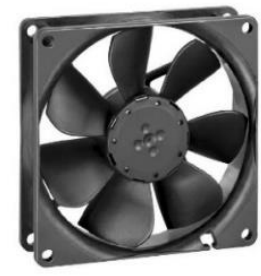

Figure $5 \mathrm{PC}$ fans

Source: ventiladores/

https://www.profesionalreview.com/

The irrigation system controls soil moisture and is composed of the HL-69 soil moisture sensor (Figure 6). The type of mist irrigation is used that expels water in the form of mist by means of eight nebulizers so that the water particles are distributed long enough to keep the crops moist.

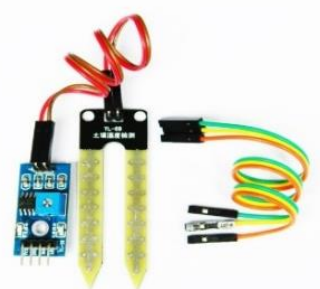

Figure 6 Soil moisture sendor HL-69

Source: $\quad$ https://www.nova.com.bo/sensor-dehumedad-de-suelo-hl69-higrometro.html

The irrigation system is placed inside the greenhouse lid and obtains the water through a COALLA electric water pump, model COO6621 (Figure 7), which allows it to be mounted in small spaces due to its size and low power consumption, as well as a garden hose. A filtering system was also implemented to ensure the cleaning of excess irrigation water, which consists of a transparent nylon net.

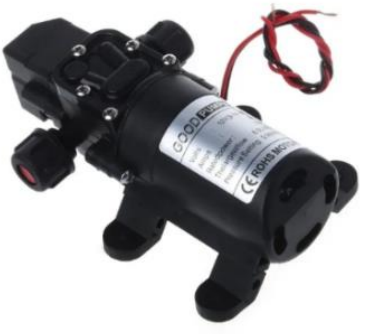

Figure 7 COALLA electric water pump, model COO6621 Source:https://www.fandeal.com/bomba-de-aguainteligente-de-70-w-6l-min-cc-12-v.html

The lighting system is in charge of constantly measuring the solar radiation received and, according to the parameters, providing a suitable light environment for growing. Because the greenhouse container is closed, in the form of a tunnel, lighting is essential. One of the alternatives that have been used in recent years for urban agriculture, where crops grow in closed, limited spaces without sunlight, is LED lighting. Four led lamps were adapted (Figure 8), which are located on the edges of the greenhouse lid, which are connected in series to the LM2596 voltage regulator (Figure 9). The integrated circuit provides the ability to regulate or decrease the input voltage, adjustable for the user through a precision potentiometer.

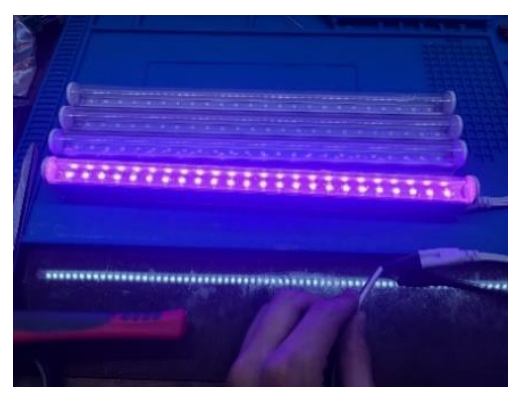

Figure 8 LED lighting

Source: Self made

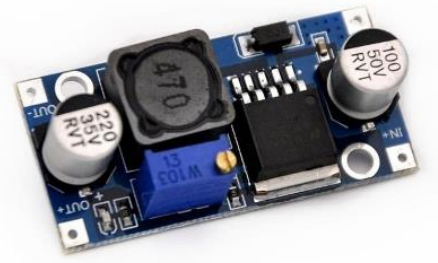

Figure 9 Voltage Regulator LM2596

Source: https://electronicastore.net/150-modulo-lm2596regulador-de-voltaje-125-a-35v-y-3-amp.html

At the end of the assembly of elements that make up the prototype, there is an estimated cost below $\$ 4000$ pesos for the automated greenhouse system that is presented in this article.

ÁLVAREZ-TORRES, Norma Angélica, VELARDE-ANAYA, Omar, RODRÍGUEZ-ARENAS, Mario Balvanedo and TORRES-ÁLVAREZ, Sara. Sustainable and low-cost automated greenhouse prototype with a social focus for integral formation. Journal of Technology and Innovation. 2021 


\section{Community analysis for greenhouse application}

The Private Assistance Institution (IAP) "Manitas que Hablan" was founded in 2010, in Nogales Sonora, with the purpose of nondiscrimination and inclusion in regular schools of children and young people with hearing and language disabilities. It currently serves 40 children and young people from 1 year 6 months to 24 years, and at an educational level from preschool to University. It offers teaching of Lengua de Señas Mexicana (LSM), auditory training, pedagogical support, inclusion in regular schools, as well as LSM courses to any hearing person who wishes to learn.

As of 2021, it is an institution whose operating expenses are paid by parents, students, and administrative staff through raffles, donations, and food sales. The automated greenhouse prototype is implemented in this institution, in order to provide crops for consumption, as well as to collaborate with the children and adolescents that make up the IAP, to generate an urban agriculture movement, adopting food production systems, care of the environment and human body.

The inclusion of young people with hearing disabilities in the activities of "family gardens" to generate in them sensitivity on these issues, ranging from learning and notions about the natural processes of planting and growing plants, to the vision of the use for family consumption and even small businesses, not to mention also developing their awareness of ecology and respect for the environment.

All of the above will allow IAP to offer a class or teaching subject on Ecology in a practical and sustainable way, to have students with a better awareness of their environment and, in addition, the possibility of generating their own economic income from the sale of their organic products, which can range from individual commerce to the development of more elaborate products such as preserves, sauces, and others for sale in the region.

"Manitas que Hablan" has an installation with a surplus patio, the land has a dimension of $6 \mathrm{~m}^{2}$, for which it was necessary to design a practical prototype, creating the greenhouse effect, in addition to resisting the outside environment.
The geographical situation of this institution (Figure 10) is oriented from north to south, giving the opportunity to obtain the best use of the sun coming out of the east and hiding in the west.

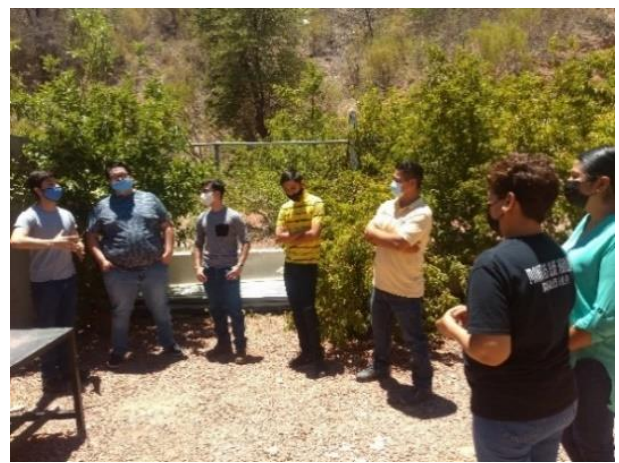

Figure 10 Manitas que hablan patio Source: Self made

In the experimental design of the prototype, adequate germination was obtained for the tomato seed. (Figure 11).

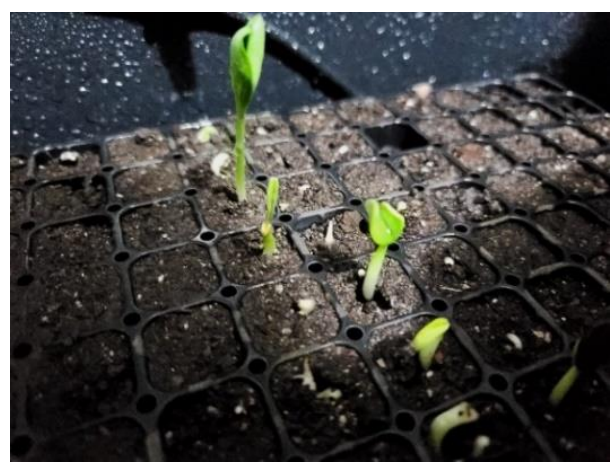

Figure 11 Seed germination Source: Self made

As previously mentioned, the type of greenhouse used was tunnel (Figure 12) with the following dimensions: width: $0.6 \mathrm{~cm}$; height $1.40 \mathrm{~m}$ (including container); length $1.05 \mathrm{~m}$ and a space for germination of the seeds of $1 \times 0.60$ $\mathrm{cm}$. The material used for the structure is metal and the high-density plastic container $(200 \mathrm{Lt}$ recycled container). There are two levels: the first level will be used as a water supply, supplying the greenhouse plants whenever necessary; on the second level, there is a trunk, the base of which is divided into two sections: one for the germination stage, in which the seeds take 5 to 15 days to sprout; the other, for transplanting the seedling and continuing its growth. 


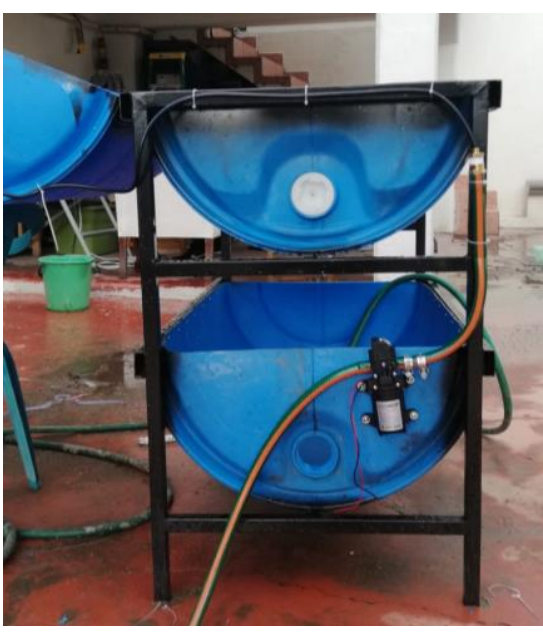

Figure 12 Tunnel type greenhouse Source: Self made

In automated greenhouses, it is important to have data control to provide an ideal environment for growing different vegetables. Light, humidity, ventilation and temperature are controlled and artificial, so the only way to recreate the right environment for planting is to control it automatically. A database was added to the prototype in Microsoft Access (Figure 13), to store the germination parameters and cultivation recommendations (INIA, 2008), to program them automatically, once the user chooses the type of seed to be sown.

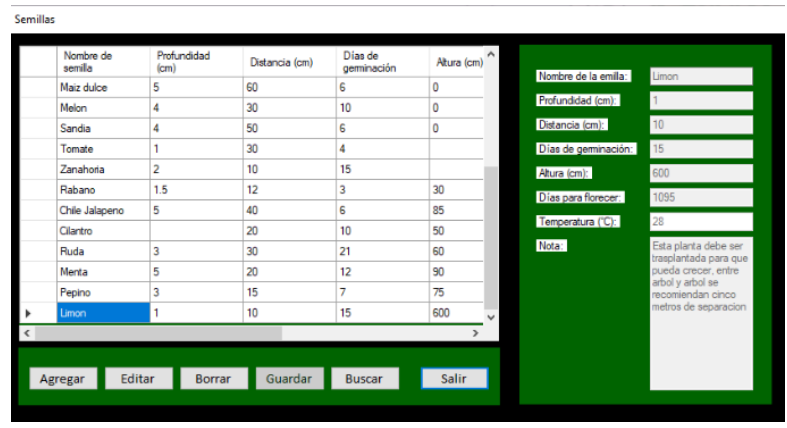

Figure 13 Database

Source: Self made

An interface was created in LabVIEW (Figure 14) for the parameters monitoring and control of the greenhouse. Consists of nine sections with the different systems that make up the prototype, including an emergency stop button, to close the program and stop the operation of the Arduino board.

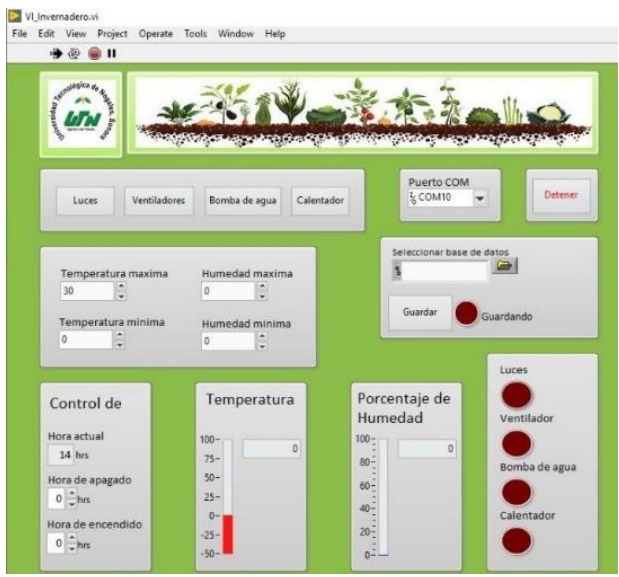

Figure 14 User Interface in LabVIEW

Source: Self made

\section{Development}

Analysis of dimension of the land for the application of the greenhouse, type of soil, and orientation of the sun.

Analysis of parameters for the vegetables cultivation and protection of information in database.

- Definition of greenhouse type and structure design.

Configure sensors for temperature, humidity, irrigation and lighting systems.

Development and implementation of the user interface in LabVIEW, based on the parameters established in the database, to monitor the behavior of the prototype systems.

Application of greenhouse tests, based on the parameters indicated in the tomato seed system.

The development of the greenhouse prototype was carried out with the collaboration of seven mechatronics students, who were in charge of carrying out the research and development of each of the systems, databases, programming, and integration. The circuit design can be seen in Figure 15. 


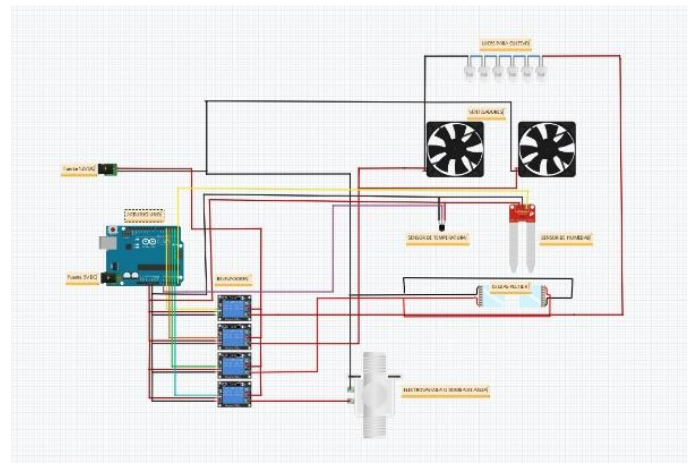

Figure 15 System Circuit Source: Self made

\section{Methodology}

A description of the development of the research work is made through an experimental methodology. Starting with a field investigation on the type of greenhouse, size and materials available to achieve a microclimate for growing vegetables, complying with the parameters according to each seed and the place where its implementation will take place. Simultaneously, a bibliographic search was carried out to determine the procedures in the development of the greenhouse, ending with the construction and programming of a functional and low-cost prototype, with the ability to install in reduced spaces and achieve the cultivation of vegetables.

\section{Results}

As part of the cultivation needs of "Manitas que Hablan", the study began with tests on various seeds, with the care established according to the germination parameters, achieving the growth of the plant. Figure 16 shows the growth of the plant from the germinated seeds, applying an artificial microclimate.

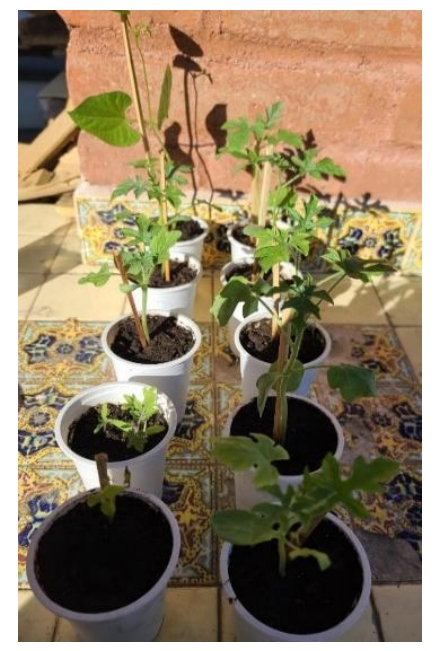

Figure 16 Seed growth

Source: Self made

\section{Conclusion}

The automated, sustainable, and low-cost greenhouse prototype with a social approach for comprehensive training is an opportunity to generate suitable environments for each seed to have results according to its conditions, taking into account the care and application of technology. It is an accessible alternative for installation in homes, parks, and communities in Mexico, both economically and in size. It significantly promotes sustainability through the cultivation of vegetables for human consumption, low cost, and whose care is carried out automatically. The function of the project is to provide adequate conditions to achieve the germination and cultivation of vegetables, in addition to monitoring the conditions of the plant.

As future work, the continuity of tests on various seeds is suggested, in such a way that the efficiency of the parameters established in the database can be verified; include an alert system to prevent excessive light exposure and temperature rise; apply other hardware, such as Raspberry Pi and an Android application as an alternative to verify project behavior; implement a photovoltaic system that replaces the connection to an electrical flow, in such a way that the prototype can be implemented in isolated places, with no power supply range.

\section{References}

Agricultura, O. d. (s.f.). (El estado mundial de la agricultura y la alimentación 2020) Recuperado el 11 de 09 de 2021, de http://www.fao.org/stateof-food-agriculture/es/

García, E. (2004). Modificaciones al sistema de Clasificación Climática de Köppen. UNAM. Obtenido de http://www.sema.gob.mx/SRN/SIIAEC/POETE /CUADROS/Cuadro_6_Descripcion_de_los_Ti pos_de_Climas.pdf

INEGI. (2020). INEGI. Población. Obtenido de https://www.inegi.org.mx/temas/estructura/

INIA, U. d. (2008). Alimentos para la huerta, guía para la producción y consumo saludable. Montevideo. 
Pérez Vázquez Arturo, L. T. (2018). Desafíos y Propuestas para lograr la seguridad alimentaria hacia el año 2050. Revista Mexicana de Ciencias Agrícolas, 175-189.

Population, P. (2020). Pirámides de población del mundo desde 1950 a 2100. Obtenido de https://www.populationpyramid.net/es/m\%C3\% A9xico/2020/

Sandoval G. Arturo P., E. J. (2008). Celdas peltier: Una alternativa para sistemas de enfriamiento con base en semiconductor. Huajuapan de León, Oaxaca, México.

SIAP, S. d. (2019). Panorama Agroalimentario 2019. México.

Unidas, N. (s.f.). Naciones Unidas. Obtenido de https://www.un.org/es/global-issues/population

Wheather, S. (2021). Datos históricos meteorológicos de 2021 en Nogales. Obtenido de

https://es.weatherspark.com/h/y/2842/2021/Tie mpo-hist\%C3\%B3rico-durante-2021en-

Nogales-M\%C3\%A9xico\#Figures-Temperature 